\title{
OBSERVATIONS RELATED TO THE IMPACT OF LUNIK ॥
}

\author{
By G. FIELDER \\ Director, Lunar Section, British Astronomical Association
}

$\mathrm{T}$ THE accompanying table gives particulars of observations which may be related to the impact of Lunik II with the Moon.

These observations refer to at least four different spots on the Moon's surface and cannot all refer to the impact of the instrument container of Lunik II. However, more than one object may have hit the Moon. From the point of view of position, it will be noted that most of the observations are consistent with the radio result. Those not consistent in this respect are asterisked. Photographs of moderate quality taken from the Pic-du-Midi, and from G. A. Hole's Observatory at Patcham, before and after the impact of the instrument container, do not appear to confirm any of the above observations.

OBSERYATIONS WHICH MAY BE RELATED TO THE IMPACT OF LUNik II

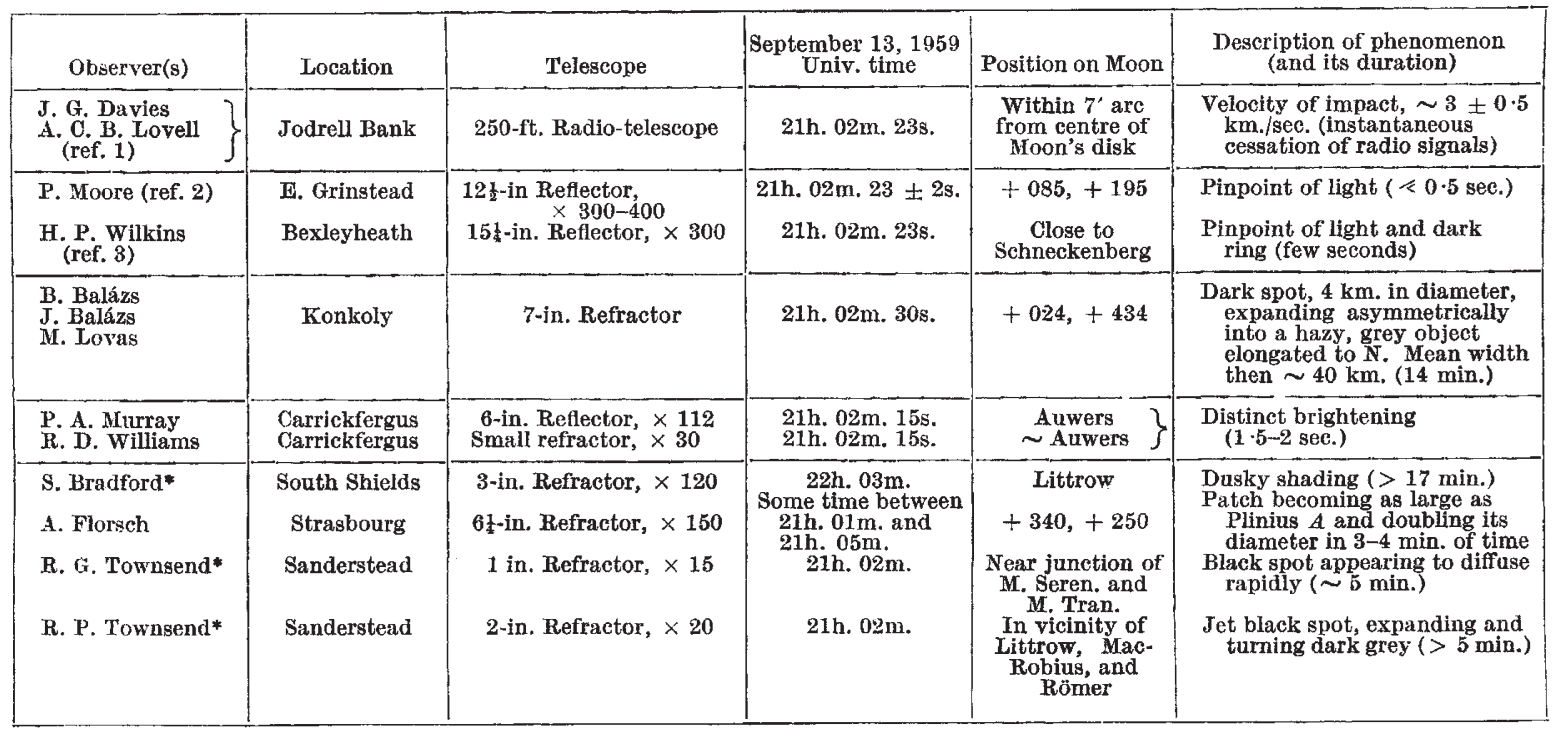

${ }^{1-3}$ Nature, 184, 501 (1959).

\section{NEWS and VIEWS}

National Institute for Research in Dairying :

Dr. A. T. R. Mattick

Dr. A. T. R. Matriok, until September 30 deputy chief scientific officer on the staff of the National Institute for Research in Dairying at Shinfield, retired on that date, having reached the age limit. Apart from the period 1915-19, when he served in the First World War in the Royal Army. Medical Corps, the whole of his working life has been spent at the Institute, which he has seen grow from very small beginnings to its present status as the outstanding dairy research institute in the Commonwealth, if not in the world. In 1919, he became a graduate assistant to Dr. R. Stenhouse Williams, and succeeded the latter as head of the young Institute's Bacteriology Department in 1929. He became deputy director in 1948, still retaining the headship of the Bacteriology Department. In October 1958, on the retirement of Prof. H. D. Kay, he became acting director.

The development, during the past thirty years, of sound methods of dairy hygiene, both in Britain and in countries abroad owes a very great deal to Mattick and his colleagues. When Mattick took it over, his Department at Shinfield had a scientific staff of three only, and its resources were meagre. With increasing funds and accommodation since 1933, and a carefully selected, growing staff, the early pioneer work was extended not only to cover the wide field of the application of microbiological science to the main problems of the dairy industry, but also to make substantial contributions to our basic know. ledge of micro-organisms. Thus, on one hand, his laboratory was largely responsible for defining the exact conditions of heat exposure necessary in the continuous process now almost universally employed in Britain for the pasteurization of milk (conditions duly incorporated into the official regulations), and on the other hand, for the detection, isolation and identification of the interesting and powerful antibiotic nisin, produced by a streptococcus that he isolated from milk, and now being used industrially. These are but two examples from many that could be 